\title{
Bioremediation of maleic anhydride contaminated soil
}

\author{
C. Y. Yin ${ }^{1,4}$, H. S. $\mathrm{Ng}^{2}$ \& S. Abdul-Talib ${ }^{3,4}$ \\ ${ }^{I}$ Faculty of Chemical Engineering, Universiti Teknologi MARA, Malaysia \\ ${ }^{2}$ ENSR Corporation Sdn Bhd., Kuala Lumpur, Malaysia \\ ${ }^{3}$ Faculty of Civil Engineering, Universiti Teknologi MARA, Malaysia \\ ${ }^{4}$ Environmental Engineering Technical Division, \\ The Institution of Engineers, Malaysia
}

\begin{abstract}
This paper presents a bench-scale study of bioremediation of soil contaminated with maleic anhydride. A quantity of $300 \mathrm{~kg}$ of contaminated soil was collected from a petrochemical plant in Malaysia and divided into three portions in order to investigate the effects of nutrient addition as well as mechanical aeration on the biodegradation rate of the contaminants. Online parameters measured included moisture content, redox potential, temperature and $\mathrm{pH}$. The highest first-order biodegradation rate constant was determined to be 6.658 day $^{-1}$ for soil pile with addition of nutrients and mechanical aeration.
\end{abstract}

Keywords: bioremediation, maleic anhydride, petrochemical industry.

\section{Introduction}

Bioremediation is an established means of treating contaminated soils especially when the contaminants are organic-based. Research in bioremediation is often focused on ex-situ bench-scale studies as such setups facilitate control of important experimental parameters such as temperature and $\mathrm{pH}$. Previous studies on ex-situ bench-scale bioremediation include biodegradation of hydrocarbon petroleum contaminated soil [1], gasoline-contaminated sediments [2] and diesel-contaminated soil [3].

Maleic anhydride is used as a chemical intermediate in the synthesis of fumaric and tartaric acid, certain agricultural chemicals, resins in numerous products, dye intermediates and pharmaceuticals [4]. Its detrimental effects on 
human health include dyspnea [5] as well as acute asthmatic reactions [6]. Its presence at elevated concentrations in the soil environment as a result of industrial activities such as hydrocarbon processing presents an undesirable circumstance as humans may come into direct contact with them. In this study, soil contaminated with maleic anhydride was subjected bioremediation processes. The objective of this study was to assess the biotreatability of maleic anhydride contaminated soil via determination of biodegradation rate and halflife of the contaminant under the effect of nutrient addition and aeration.

\section{Materials and methods}

\subsection{Soil sampling}

Soil samples were taken from a petrochemical plant in Malaysia, which were contaminated with maleic anhydride due to improper storage and leakage. A total of $300 \mathrm{~kg}$ of contaminated soil was collected at depths between 3 to $4 \mathrm{~m}$ at the affected area within the petrochemical plant. The soil appeared to be coarse and dark brown in color. The $\mathrm{pH}$ of the soil sample was adjusted to 7 by using lime prior to treatment.

\subsection{Bench-scale treatment}

Due to the readily biodegradable properties of maleic anhydride as determined via a preliminary study, bioremediation was selected as the most appropriate treatment option. For the bench-scale treatment, three soil piles at $100 \mathrm{~kg}$ each were constructed:

i) Control soil pile (CP).

ii) Treatment pile mixed with raw nutrients and sawdust (TP1).

iii) Treatment pile mixed with raw nutrients, sawdust and equipped with mechanical aerators (TP2).

The source of the raw nutrients was chicken faeces in which the carbon and nitrogen ratio was 1:30. Sawdust layers, which acted as partition for the soil piles, were laid in three layers sandwiching two layers of soil. The sawdust and soil composition was fixed at $30 \%$ on $\mathrm{v} / \mathrm{v}$ basis. The mechanical aerators for TP2 consisted of two-inch diameter slotted perforated pipes with attached mechanical blower. The three piles were subjected to a monitoring program for a period of two months in which online parameters measured included moisture content, redox potential, temperature and $\mathrm{pH}$. The concentrations of maleic anhydride before and after treatment were determined via high performance liquid chromatography (HPLC).

\section{Results and discussion}

The initial concentration of maleic anhydride was determined to be 223,000 $\mathrm{mg} / \mathrm{kg}$ soil respectively. The concentration of maleic anhydride that exceeds the U.S. Environmental Protection Agency (USEPA) preliminary remediation goal 
of $88,000 \mathrm{mg} / \mathrm{kg}$ indicates the need to remediate the soil. Table 1 shows the online parameters recorded during the study period. The range of temperatures in the three soil piles indicates that mesophilic microorganisms are mainly responsible for biodegradation of the contaminants. This is consistent with most of the reported studies on bioremediation in which recorded temperatures were in the mesophilic range $[7,8]$. In addition, redox potential ranges clearly show that degradation predominantly occurs under aerobic conditions.

Table 1: $\quad$ Online parameters recorded during the study period.

\begin{tabular}{|l|c|c|c|c|}
\hline Soil piles & $\begin{array}{c}\text { Moisture } \\
\text { content }(\%)\end{array}$ & $\begin{array}{c}\text { Redox potential } \\
(\mathrm{mV})\end{array}$ & $\begin{array}{c}\text { Temperature } \\
\left({ }^{\circ} \mathrm{C}\right)\end{array}$ & $\mathrm{pH}$ \\
\hline CP & $9.2-25.8$ & $207-287$ & $28-35$ & $3.8-8.2$ \\
\hline TP1 & $6.6-44.0$ & $82-203$ & $27-41$ & $4.9-8.5$ \\
\hline TP2 & $3.6-36.0$ & $92-201$ & $26-38$ & $6.7-8.9$ \\
\hline
\end{tabular}

\subsection{Biodegradation kinetics}

The biodegradation kinetics are evaluated via determination of first-order degradation rate constant, $k^{\prime}\left(\right.$ day $\left.^{-1}\right)$ and half-life of the chemical, $t_{1 / 2}$ (day). To determine the value of $k^{\prime}$, the following equation [9] is used:

$$
S_{t}=S_{0} e^{-k^{\prime} t}
$$

where $S_{0}$ is the initial contaminant concentration $(\mathrm{mg} / \mathrm{L})$ and $S_{t}$ the contaminant concentration at time $t$ (day). Half-life is determined from the following equation [9]:

$$
k^{\prime}=\frac{0.693}{t_{1 / 2}}
$$

Table 2 shows the first-order degradation rate constant and half-life of maleic anhydride in the soil piles. The addition of nutrients into the soil clearly increase the degradation rate as evident by the increase in $k$ ' value by a factor of nine. Aeration of the soil in TP2 also appears to increase the biodegradation rate constant by $12.2 \%$ as compared to $\mathrm{TP} 1$. This is due to increased concentration of oxygen in the TP2 as a direct result of aeration. Table 3 compares first-order degradation rate constants for maleic anhydride found in this study with other contaminants. It is obvious that biodegradation of maleic anhydride in this study is very effective as compared to degradation of other hydrocarbon contaminant such as diesel.

Table 2: First-order degradation rate constant and half-life of maleic anhydride.

\begin{tabular}{|l|c|c|}
\hline Soil piles & $k^{\prime}\left(\right.$ day $\left.^{-1}\right)$ & $t_{l / 2}$ (day) \\
\hline CP & 0.592 & 1.1 \\
\hline TP1 & 5.935 & 0.1 \\
\hline TP2 & 6.658 & 0.1 \\
\hline
\end{tabular}


Table 3: Comparison of first-order degradation rate constants with other contaminants.

\begin{tabular}{|c|c|c|c|}
\hline Contaminant & Addition of nutrient & $k^{\prime}\left(\right.$ day $\left.^{-1}\right)$ & References \\
\hline Diesel-contaminated soil & Yes & 0.027 & {$[10]$} \\
\hline Diesel-contaminated soil & No & 0.010 & {$[10]$} \\
\hline Diesel-contaminated soil & Yes (sewage sludge) & 0.272 & {$[11]$} \\
\hline Diesel-contaminated soil & Yes (compost) & 0.182 & {$[11]$} \\
\hline Diesel-contaminated soil & No & 0.052 & {$[11]$} \\
\hline $\begin{array}{c}\text { Maleic anhydride- } \\
\text { contaminated soil }\end{array}$ & No & 0.592 & This study \\
\hline $\begin{array}{c}\text { Maleic anhydride- } \\
\text { contaminated soil }\end{array}$ & Yes (Chicken faeces) & 5.935 & This study \\
\hline
\end{tabular}

\section{Conclusions}

Biodegradation of maleic anhydride in the soil was carried out by mesophilic microorganisms under aerobic conditions. Results of the study indicated that bioremediation of maleic anhydride in soils was effective and feasible judging by the high biodegradation rate. The addition of nutrients into the contaminated soil significantly increased the maleic anhydride biodegradation rate as evident by the increase in $k$ ' value by a factor of nine. Aeration of the soil in TP2 increased the biodegradation rate constant by $12.2 \%$ as compared to TP1.

\section{References}

[1] Aspray, T.J., Carvalho, D.J.C. \& Phillip, J.C., Application of soil slurry respirometry to optimise and subsequently monitor ex situ bioremediation of hydrocarbon-contaminated soils. International Biodeterioration \& Biodegradation, 60(4), pp. 279-284, 2007.

[2] Baker, R.J., Baehr, A.L. \& Lahvis, M.A., Estimation of hydrocarbon biodegradation rates in gasoline-contaminated sediment from measured respiration rates. Journal of Contaminant Hydrology, 41, pp. 175-192, 2000.

[3] Cunningham, C.J. \& Philp, J.C., Comparison of bioaugmentation and biostimulation in ex situ treatment of diesel contaminated soil. Land Contamination and Reclamation, 8(4), pp. 261-269, 2000.

[4] HSDB, Hazardous Substances Data Bank. National Library of Medicine, Bethesda, MD (TOMESÒ CD-ROM Version). Denver, CO: Micromedex, Inc., 1995.

[5] Gannon, P.F.G., Burge, P.S., Hewlett, C. \& Tee R.D., Haemolytic anaemia in a case of occupational asthma due to maleic anhydride. British Journal of Industrial Medicine, 49, pp. 142-143, 1992.

[6] Lee, H.S., Wang, Y.T., Cheong, T.H., Tan, K.T., Chee B.E. \& Narendran, K., Occupational asthma due to maleic anhydride. British Journal of Industrial Medicine, 48, pp. 283-285, 1991. 
[7] ChaoA neau, C.H., Morel, J.L. \& Oudot, J., Microbial degradation in soil microcosms of fuel oil hydrocarbons from drilling cuttings. Environment Science and Technology, 29, pp. 1615-1621, 1995.

[8] Fu, C., Pfanstiel, S., Gao, C., Yan, X. \& Govind, R., Studies on contaminant biodegradation in slurry, water and compacted soil tube reactors. Environment Science and Technology, 29, pp. 1615-1621, 1995.

[9] LaGrega, M.D., Buckingham, P.L. \& Evans, J.C., Hazardous Waste Management, McGraw-Hill: International Edition, pp. 553-653, 2001.

[10] Taylor, C. \& Viraraghavan, T., A bench-scale investigation of land treatment of soil contaminated with diesel fuel. Chemosphere, 39(10), pp. 1583-1593, 1999.

[11] Namkoong, W., Hwang, E.Y., Park, J.S. \& Choi, J.Y., Bioremediation of diesel-contaminated soil with composting. Environmental Pollution, 119(1), pp. 23-31, 2002. 